\title{
The relationship between alcohol- related hospital admission and specialist alcohol treatment provision across local authorities in England since passage of the Health and Social Care Act 2012
}

\author{
Emmert Roberts, Matthew Hotopf and Colin Drummond
}

\begin{abstract}
Summary
To our knowledge no previous studies have been conducted at the local authority level assessing relationships between alcoholrelated hospital admission, specialist alcohol treatment provision and socioeconomic deprivation since the UK government passed the Health and Social Care Act in 2012. Our results, using publicly available national data-sets, suggest that the local authority areas in England most in need of adequately funded specialist alcohol treatment, because of high prevalence of alcohol dependence and deprivation, are not receiving targeted increased funding, and that the national rise in alcohol-related hospital admissions may be fuelled by local authority funding cuts to specialist alcohol treatment.
\end{abstract}

\section{Keywords}

Alcohol; commissioning; funding; localism; policy.

\section{Copyright and usage}

(c) The Authors, 2020. Published by Cambridge University Press on behalf of The Royal college of Psychiatrists. This is an Open Access article, distributed under the terms of the Creative Commons Attribution licence (http://creativecommons.org/ licenses/by/4.0/), which permits unrestricted re-use, distribution, and reproduction in any medium, provided the original work is properly cited.
In March 2012 the Health and Social Care Act (HSCA) gained royal assent under the UK coalition government. This cemented in legislation the transfer of specialist drug and alcohol service commissioning responsibilities from the National Health Service (NHS) and placed this statutory duty solely within the remit of local authorities. The stated rationale was that a localist approach to treatment commissioning and delivery would enable the provision of necessary resources, while allowing flexibility to take into account local needs.

Since passage of the HSCA there have been major changes in the addiction treatment provider landscape: currently approximately $65 \%$ of specialist community alcohol services are provided by independent sector agencies, whereas before the HSCA over $90 \%$ of services were provided by the NHS. ${ }^{1}$ Critics of the localist approach point to the removal of ring-fenced drug and alcohol budgets and year-on-year increases in alcohol-related hospital admissions since the statute's enactment. ${ }^{2}$ Conversely, proponents point to increased local innovation ${ }^{3}$ and the removal of challenges associated with the implementation of national policies.

Although there has been impact evaluation of alcohol policy decentralisation at the level of individuals and devolved nations, ${ }^{4}$ to our knowledge no previous studies have been conducted at the local authority level that attempt to assess the relationship between alcohol-related hospital admission, specialist alcohol treatment provision and deprivation since implementation of the changes within the HSCA. We examined publicly available national data in England in an attempt to address this gap.

\section{Method}

Annual estimates for nine metrics were extracted from publicly available data sources for each of the 152 local authorities in England (Table 1). These metrics represent official local authority-level measures of specialist treatment access, treatment success and treatment funding, alcohol-related hospital admissions, alcohol disease burden and socioeconomic deprivation.

Data were extracted for the previous six financial years for which local authorities have had complete control of drug and alcohol service commissioning (2013-2014 to 2018-2019), with 2013-2014 taken as the baseline for comparison. Alcoholrelated hospital admissions are classified as either 'narrow' or 'broad', depending on whether an alcohol-attributable disease is coded as the primary reason, or as 1 of up to 19 secondary reasons, for hospital admission. ${ }^{5}$ Local authorities have separately reported net expenditure for alcohol misuse treatment and net expenditure for preventing and reducing harm from alcohol misuse to the Department for Communities and Local Government since 2016-2017. We therefore took 2016-2017 as the baseline for expenditure data. All expenditure data were adjusted for inflation using the UK gross domestic product (GDP) deflator. ${ }^{6}$

For metrics with repeated measures available, the mean change per financial year for each metric was calculated for each local authority. For metrics where repeated measures were not available, baseline data for each local authority were recorded. Univariate linear regression with robust standard errors assessed the association of each metric with 'broad' and 'narrow' alcohol-related hospital admission. Where a significant association was demonstrated we planned to introduce those variables into multivariate linear regression models and reported the adjusted impact of treatment provision, alcohol disease burden and deprivation on alcoholrelated admissions. In addition, the mean absolute and percentage change in each metric per year averaged across all local authorities was generated.

The study did not require ethical approval as it did not involve human participants. All analyses were conducted in STATA/IC for Mac version 15 with the significance level set at 0.05 . 
Table 1 Measures of alcohol-related hospital admission, specialist alcohol treatment provision, alcohol disease burden and deprivation by local authority area in England ${ }^{\mathrm{a}}$

\begin{tabular}{|c|c|c|c|c|c|}
\hline Metric & $\begin{array}{l}\text { What are we } \\
\text { measuring? }\end{array}$ & Data source & $\begin{array}{l}\text { Baseline per local } \\
\text { authority, mean } \\
\text { (range) }\end{array}$ & $\begin{array}{l}\text { Change per year per } \\
\text { local authority, mean } \\
\text { absolute change (range) }\end{array}$ & $\begin{array}{l}\text { Change per year per } \\
\text { local authority, mean } \\
\text { percentage change }\end{array}$ \\
\hline \multicolumn{6}{|c|}{ Measures of alcohol-related hospital admission } \\
\hline $\begin{array}{l}\text { Age-standardised adult rate of alcohol- } \\
\text { related admissions per } 100000 \\
\text { population (narrow) }\end{array}$ & $\begin{array}{l}\text { - Measure of alcohol- } \\
\text { related harm }\end{array}$ & $\begin{array}{l}\text { - Local Alcohol } \\
\text { Profiles }^{b}\end{array}$ & $\begin{array}{c}657.17(366.34- \\
1230.51)\end{array}$ & $+6.25(-43.08$ to 49.81$)$ & $+0.95 \%$ \\
\hline $\begin{array}{l}\text { Age-standardised adult rate of alcohol- } \\
\text { related admissions per } 100000 \\
\text { population (broad) }\end{array}$ & & & $\begin{array}{l}2227.14(1115.19- \\
3493.34)\end{array}$ & $+59.57(-72.39$ to 343.75$)$ & $+2.67 \%$ \\
\hline \multicolumn{6}{|c|}{ Measures of specialist alcohol treatment provision } \\
\hline $\begin{array}{l}\text { Net local authority adult expenditure } \\
\text { on treatment for alcohol misuse per } \\
1000 \text { population, } \mathrm{f}\end{array}$ & $\begin{array}{l}\text { Measure of } \\
\text { treatment } \\
\text { funding }\end{array}$ & $\begin{array}{l}\text { Local authority } \\
\text { revenue } \\
\text { expenditure and } \\
\text { financingc }\end{array}$ & f3857 (521-15 788) & $-£ 147(-5551$ to 3179$)$ & $-3.81 \%$ \\
\hline $\begin{array}{l}\text { Net local authority adult expenditure } \\
\text { on preventing and reducing harm } \\
\text { from alcohol misuse per } 1000 \\
\text { population, } \mathrm{E}\end{array}$ & & & $£ 1126(24-7420)$ & $-f 88(-8080$ to 1655$)$ & $-7.82 \%$ \\
\hline $\begin{array}{l}\text { Proportion of adults in specialist } \\
\text { alcohol treatment who successfully } \\
\text { completed treatment for alcohol } \\
\text { dependence and did not re-present } \\
\text { within } 6 \text { months, \% }\end{array}$ & $\begin{array}{l}\text { Measure of } \\
\text { treatment } \\
\text { success }\end{array}$ & $\begin{array}{l}\text { Local Alcohol } \\
\text { Profiles }^{\mathrm{b}}\end{array}$ & $37.40 \%(15.13-67.58)$ & $+0.07 \%$ & $+0.07 \%$ \\
\hline $\begin{array}{l}\text { Adult treatment rate in specialist } \\
\text { alcohol misuse services per } 1000 \\
\text { population }\end{array}$ & $\begin{array}{l}\text { Measure of } \\
\text { treatment } \\
\text { access }\end{array}$ & $\begin{array}{l}\text { Public Health } \\
\text { Profiles }^{d}\end{array}$ & $2.39(0.67-6.19)$ & $-0.12(-1.44$ to 0.46$)$ & $-5.02 \%$ \\
\hline $\begin{array}{l}\text { Proportion of adults with alcohol } \\
\text { dependence not in treatment, \% }\end{array}$ & & & $80.07 \%(58.64-94.83)$ & n.a. & n.a. \\
\hline \multicolumn{6}{|l|}{ Measures of alcohol disease burden } \\
\hline Alcohol dependence prevalence, $\%{ }^{\mathrm{e}}$ & $\begin{array}{l}\text { Measure of disease } \\
\text { burden }\end{array}$ & $\begin{array}{l}\text { Local Alcohol } \\
\text { Profiles }^{\mathrm{b}}\end{array}$ & $1.48 \%(0.64-3.85)$ & n.a. & n.a. \\
\hline $\begin{array}{l}\text { Measures of socioeconomic deprivation } \\
\text { Indices of multiple deprivation (IMD) }\end{array}$ & $\begin{array}{l}\text { Measure of } \\
\text { deprivation }\end{array}$ & $\begin{array}{l}\text { Local Authority } \\
\quad \text { Health Profiles }^{f}\end{array}$ & $26.38(7.81-36.17)$ & n.a. & n.a. \\
\hline \multicolumn{6}{|c|}{ 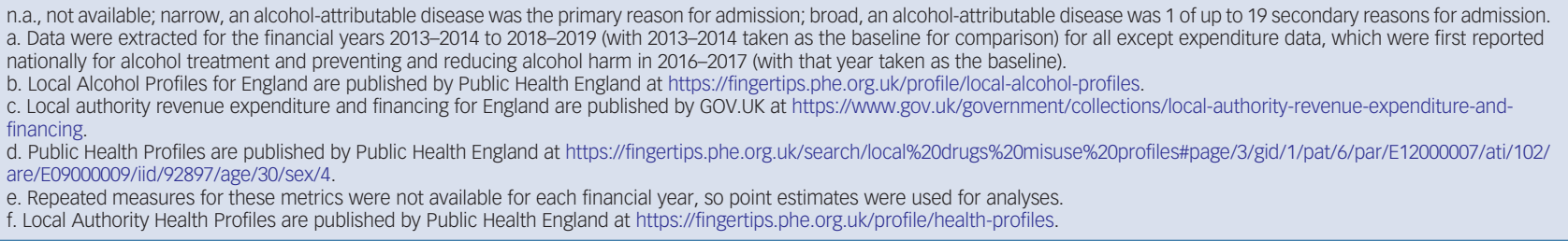 } \\
\hline
\end{tabular}

\section{Results}

The results confirm previously observed national trends in alcoholrelated hospital admissions: a mean increase per local authority of $6.25(0.95 \%)$ for 'narrow' admissions and 59.57 (2.67\%) for 'broad' admissions, per 100000 population per year.

We confirmed the national reduction in the rate of entry into specialist alcohol treatment per local authority of 0.12 people (5.02\%) per 1000 people per year. However, of those attending specialist alcohol treatment services the percentage who successfully completed treatment and did not re-present within 6 months increased by a rate of $0.07 \%$ per year.

The data suggest a mean decrease in net expenditure per 1000 people of $£ 147$ (3.81\%) for alcohol misuse treatment and $£ 88$ (7.82\%) for preventing and reducing alcohol misuse, per year. There was considerable heterogeneity in the change in expenditure between local authorities $\left(I^{2}=99 \%\right)$, with $90 / 148$ local authorities (60.81\%) observed to have experienced a mean reduction in annual net expenditure for treatment of alcohol misuse since 2016-2017.

The change in the rate of 'narrow' hospital admissions per local authority was associated only with that local authority's baseline alcohol dependence prevalence and the percentage of adults with alcohol dependence not in treatment. The increased rate of 'broad' hospital admissions per local authority was associated only with the reduction in net expenditure for alcohol misuse treatment per 1000 people for that local authority $(\beta=-0.014 ; 95 \% \mathrm{CI}-0.024$ to $-0.004 ; P=0.01$ ) (supplementary Table 1 , available at http://doi. org/10.1192/bjp.2020.120). This demonstrates that, if the average local authority reduced its net annual expenditure for treatment of alcohol misuse by $5 \%$, we could expect to see an associated average increase of 60 (95\% CI 58-62) 'broad' alcohol-related hospital admissions for that local authority per 100000 people per year. To put this into context, $5 \%$ of the mean annual baseline net expenditure per 1000 population per local authority was $£ 179$.

\section{Discussion}

Our results show similar patterns to individual-level data observed since the passage of the HSCA, indicating on average year-on-year increases in alcohol-related hospital admissions and concomitant year-on-year reductions in both the number of people entering 
specialist treatment and net local authority expenditure for treatment of alcohol misuse. ${ }^{1,2}$ Although our results also suggest on average year-on-year increases in the proportion of patients successfully completing treatment, they mainly serve to highlight the considerable variation across local authorities in England in treatment access, funding and success.

The changes reported in net expenditure should be interpreted with caution, given the high heterogeneity between local authorities and because some of the reported expenditure data appear to lack face validity. For example, several local authorities reported net expenditures of $£ 0$ for alcohol misuse treatment despite our knowledge that specialist alcohol services were being provided. This may suggest inaccurate reporting of expenditure to central government, a concern that has also been raised in recent government reports. ${ }^{7}$

The increased rate of 'broad' alcohol-related hospital admissions was associated with the reduction in net expenditure for treatment of alcohol misuse. This suggests that local authority funding cuts to specialist alcohol treatment services may be displacing costs onto the NHS hospital system (details available from the author on request) and may partially explain the national increase in 'broad' alcohol-related admissions since passage of the HSCA. However, the lack of association with the reduction in the rate of people entering treatment suggests that the increases in hospital admissions may not be mediated via the falling numbers of people in specialist treatment, and thus we hypothesise that the clinical profile of individuals accessing specialist treatment may also be changing. Local authorities may be shifting away from treating individuals with severe and complex alcohol misuse in favour of those with lower-risk drinking profiles, which could lead to increased hospital admission rates for drinkers with severe and complex problems. Further work examining how changes in funding and service provider within individual local authorities is warranted to examine any change in the profile of the people accessing treatment and how any local changes in treatment provision have affected individual service users.

Our results suggest that the local authority areas in England with a high baseline prevalence of alcohol dependence and deprivation do not appear to be receiving targeted increased funding, and that the nationally observed increase in alcohol-related hospital admissions may be fueled by a reduction in expenditure for specialist alcohol treatment. When examined in the context of alcoholrelated hospital admissions, the localist approach to specialist alcohol treatment may have had unintended consequences.

\footnotetext{
Emmert Roberts (D), National Addiction Centre and Department of Psychological Medicine, Institute of Psychiatry, Psychology and Neuroscience, King's College London; and South London and Maudsley NHS Foundation Trust, UK; Matthew Hotopf (DD, Department of Psychological Medicine, Institute of Psychiatry, Psychology and Neuroscience, King's College London; and South London and Maudsley NHS Foundation Trust, UK; Colin Drummond, National Addiction Centre, Institute of Psychiatry, Psychology and Neuroscience, King's College London; and South London and Maudsley NHS Foundation Trust, UK

Correspondence: Dr Emmert Roberts. E-mail: emmert.roberts@kcl.ac.uk

First received 6 Apr 2020, final revision 20 May 2020, accepted 21 May 2020
}

\section{Supplementary material}

Supplementary material is available online at http://doi.org/10.1192/bjp.2020.120.

\section{Data availability}

The authors had full access to all study data. All data used in this study are publicly available.

\section{Author contributions}

E.R. formulated the research question, designed and carried out the study, analysed the data and drafted the article. M.H. and C.D. contributed to the formulation of the research question, study design, data analysis and writing the article. All authors take responsibility for the integrity of the data and the accuracy of the data analysis and meet the ICMJE criteria for authorship.

\section{Funding}

This work was supported by the Medical Research Council (MRC), as part of E.R.'s MRC Addiction Research Clinical (MARC) Fellowship. The research was part funded by the National Institute of Health Research (NIHR) Biomedical Research Centre at South London and Maudsley NHS Foundation Trust and King's College London, and by the NIHR Collaboration for Leadership in Applied Health Research and Care South London (NIHR CLAHRC South London), now recommissioned as NIHR Applied Research Collaboration South London. C.D. and M.H. receive funding from an NIHR Senior Investigator award. The funders had no contribution to: the study design; collection, analysis and interpretation of data; writing of the report; and decision to submit the paper for publication. All authors were independent of the funders. The views expressed are paper for publication. All authors were independent of the funders. The views expressed are those of the authors and not necessarily those of the MRC, the National Health Service (NHS),
the NIHR or the Department of Health and Social Care.

\section{Declaration of interest}

None.

CMJE forms are in the supplementary material, available online at https://doi.org/10.1192/ bjp.2020.120.

\section{References}

1 Mohammadi D. Addiction services in England: in need of an intervention. Lancet Psychiatry 2014; 1: 421-2.

2 NHS Digital. Statistics on Alcohol: England 2018. NHS Digital, 2018 (https://files. digital.nhs.uk/60/B4D319/alc-eng-2018-rep.pdf).

3 Alcohol Change UK. The Blue Light Project. Alcohol Change UK, 2020 (https:// alcoholchange.org.uk/help-and-support/get-help-now/for-practitioners/bluelight-training/the-blue-light-project).

4 O'Donnell A, Anderson P, Jané-Llopis E, Manthey J, Kaner E, Rehm J. Immediate impact of minimum unit pricing on alcohol purchases in Scotland: controlled interrupted time series analysis for 2015-18. BMJ 2019; 366: I5274.

5 Perkins P, Hennessey M. Understanding alcohol-related hospital admissions. Public Health England, 2014 (https://publichealthmatters.blog.gov.uk/2014/ 01/15/understanding-alcohol-related-hospital-admissions/).

6 HM Treasury. GDP deflators at market prices, and money GDP June 2019 (Quarterly National Accounts). HM Treasury, 2019 (https://www.gov.uk/government/statistics/gdp-deflators-at-market-prices-and-money-gdp-june2019-quarterly-national-accounts).

7 Black C. Review of Drugs: Phase One Report. Home Office, 2020 (https://www. gov.uk/government/publications/review-of-drugs-phase-one-report). 